\title{
Morphology and distribution of some marine diatoms, family Rhizosoleniaceae, genus Rhizosolenia, in Korean coastal waters
}

\author{
Suk Min Yun ${ }^{1, a}$, Sang Deuk Lee ${ }^{1}$ and Jin Hwan Lee ${ }^{1, *}$ \\ ${ }^{1}$ Department of Green Life Science, Sangmyung University, Seoul 110-743, Korea
}

\begin{abstract}
The present study describes the morphology, taxonomy, and distribution of species belonging to the diatom genus Rhizosolenia in Korea's marine coastal waters. From September 2008 to February 2010, we collected phytoplankton samples at 30 sites along the Korean coastline and studied them by light and scanning electron microscopy. We found 6 rhizosolenid genera in our samples: Rhizosolenia, Dactyliosolen, Guinardia, Pseudosolenia, Proboscia, and Neocalyptrella. In the present paper, we studied the following rhizosolenid species and compared them with congeners: R. pungens, $R$. fallax, R. imbricata, Rhizosolenia sp. 1, and Rhizosolenia sp. 2. The morphology of $R$. pungens exhibits important diagnostic characteristics in its girdle segment structure in the column and in its external process. To distinguish $R$. fallax and R. imbricata, the most important characteristics are the striation and the velum structure. $R$. pungens occurred in our samples all along the Korean coast. Only rarely did we find R. imbricata in the samples and at low abundance. We recorded R.fallax, Rhizosolenia sp. 1 and Rhizosolenia sp. 2 for the first time in Korean waters, but they rarely occurred.
\end{abstract}

Key Words: distribution; Korean waters; morphology; Rhizosolenia; scanning electron microscopy; taxonomy

\section{INTRODUCTION}

The diatom genus Rhizosolenia Brightwell (1858) is one of the most important marine diatom genera and occasionally dominates the phytoplankton biomass in highly productive oceanic regions (Sundström 1986). Traditionally, Rhizosolenia species commonly exhibit a girdle segment structure in the column and a particular shape of the external processes, otaria, claspers, and the contiguous area (Sundström 1986, Hasle and Syvertsen 1996).

Ehrenberg (1843) established Rhizosolenia, with $R$. americana as the type species. Later, Hustedt (1930), Hasle (1975), Sundström (1986), Round et al. (1990), and Hernández-Becerril and Meave del Castillo (1996, 1997) reviewed the genus. The genus Rhizosolenia comprises a number of genera with particular morphologies: Neoca- lyptrella Hernández-Becerril and Meave, Pseudosolenia Sundström, Proboscia Sundström, and Urosolenia Round and Crawford. All these genera are found solely in marine environments except Urosolenia, which is restricted to fresh waters (Edlund and Stoermer 1993, Rott et al. 2006).

Shim (1994) reported finding the genus Rhizosolenia and several species of the genus Guinardia H. Peragallo and Dactyliosolen Castracane in the family Rhizosoleniaceae in Korea's coastal waters. Lee (1995) added 2 genera to a checklist of Korean coastal waters: Proboscia and Pseudosolenia. Since then, others have performed further studies of Rhizosolenia and other related taxa in Korea. However, the species identifications, synonymies and phylogenetic system of the genus Rhizosolenia and other related taxa are yet insufficient. (c) This is an Open Access article distributed under the terms of the Creative Commons Attribution Non-Commercial License (http://creativecommons.org/licenses/by-nc/3.0/) which permits unrestricted non-commercial use, distribution, and reproduction in any medium, provided the original work is properly cited.
Received 2 February 2011, Accepted 26 April 2011

*Corresponding Author

E-mail: jhlee@smu.ac.kr

Tel: +82-2-2287-5152, Fax: +82-2-2287-0098

${ }^{a}$ Present address: Laboratory of Plankton Ecology, Korea Institute of Coastal Ecology, Inc., Bucheon 421-808, Korea 
The present study examined planktonic diatoms of the genus Rhizosolenia from coastal Korea's waters. We studied morphological details by scanning electron microscopy (SEM) and light microscopy (LM) and discussed their taxonomies and distributional data.

\section{MATERIALS AND METHODS}

From August 2008 to February 2009, we collected phytoplankton samples from Korean coastal waters (Table 1), by vertically towing a $20 \mu \mathrm{m}$ mesh net and immediately fixed the samples with neutralized formalin (final concentration 5\%), glutaraldehyde (final concentration $2 \%$ ) and Lugol's solution. To remove organic matter in the diatom cells, we used the method described by Hasle and Fryxell (1970) and Simonsen (1974). The resultant materials were examined under an Axioskop 40 light microscope (Carl Zeiss, Jena, Germany) and photographed with an MRc 5 camera (Carl Zeiss) and a scanning electron microscope (JSM-5600LV; Jeol, Tokyo, Japan). To analyze diatoms' sizes, we employed image calculation software (AxioVision AC version 4.5; Carl Zeiss). To identify previous reports of each taxon, we considered catalogues by Cupp (1943), Hendey (1964), Sundström (1986), Hasle and Syvertsen (1996). Terminology followed general proposals by Ross et al. (1979), Sundström (1986), Round et al. (1990) and Hasle and Syvertsen (1996).

\section{RESULTS}

Table 2 summarizes the characteristics we observed in the Rhizosolenia species studied here. Each description includes references for identification, LM, and SEM. Sundström (1986) suggested the following systematics and phylogenetic allocation of the members of the family Rhizosoleniaceae.

Class Bacillariophyceae Haeckel 1878

Order Centrales Hustedt 1930

Suborder Rhizosoleniineae Simonsen 1979

Family Rhizosoleniaceae De Toni 1890

Genus Rhizosolenia Brightwell 1858

R. pungens (Cleve-Euler) Brunel 1962

R. fallax Sundström 1986

R. imbricata Brightwell 1858

Rhizosolenia sp. 1

Rhizosolenia sp. 2

\section{Rhizosolenia pungens (Cleve-Euler) Brunel, 1962 (Fig. 1, A-F)}

Brunel 1962, p. 66, Pl. 4, Figs 5 \& 6; Hernández-Becerril 1995, p. 264, Figs 36-40; Hasle and Syvertsen 1996, p. 157, Pl. 30; Sar 1996, p. 381; Sunesen and Sar 2007, p. 634, Figs 35- 47 .

The cells are solitary or in pairs, cylindrical, bilaterally symmetrical, circular in cross-section, and 4.1-16.7

Table 1. Collection site information for the Rhizosolenia specimens examined in the present study

\begin{tabular}{lllll}
\hline Species & Sampling date & Location & Latitude (N) & Longitude (E) \\
\hline Rhizosolenia pungens & Feb 12, 2009 & Jeju Island & $33^{\circ} 16.571$ & $126^{\circ} 43.021$ \\
& May 03, 2009 & Daecheon Harbor & $36^{\circ} 18.203$ & $126^{\circ} 30.925$ \\
& May 20, 2009 & Wolseng & $35^{\circ} 43.836$ & $129^{\circ} 29.225$ \\
& Jun 25, 2009 & Geoje Island & $34^{\circ} 59.588$ & $128^{\circ} 40.519$ \\
& Jul 25, 2009 & Oido Island & $37^{\circ} 20.731$ & $126^{\circ} 41.181$ \\
R. fallax & Sep 22, 2008 & Yellow Sea & $35^{\circ} 30.521$ & $124^{\circ} 10.773$ \\
& Feb 12, 2009 & Jeju Island & $33^{\circ} 14.186$ & $126^{\circ} 19.985$ \\
& Feb 12, 2009 & Jeju Island & $33^{\circ} 33.087$ & $126^{\circ} 41.016$ \\
May 20, 2009 & Wolseng & $35^{\circ} 43.836$ & $129^{\circ} 29.225$ \\
R. imbricata & Jun 25, 2009 & Geoje Island & $34^{\circ} 59.588$ & $128^{\circ} 40.519$ \\
Rhizosolenia sp. 1 & Oct 15, 2009 & Yangyang & $38^{\circ} 07.411$ & $128^{\circ} 37.961$ \\
Rhizosolenia sp. 2 & Sep 22, 2008 & Yellow Sea & $35^{\circ} 30.521$ & $124^{\circ} 10.773$ \\
\hline
\end{tabular}




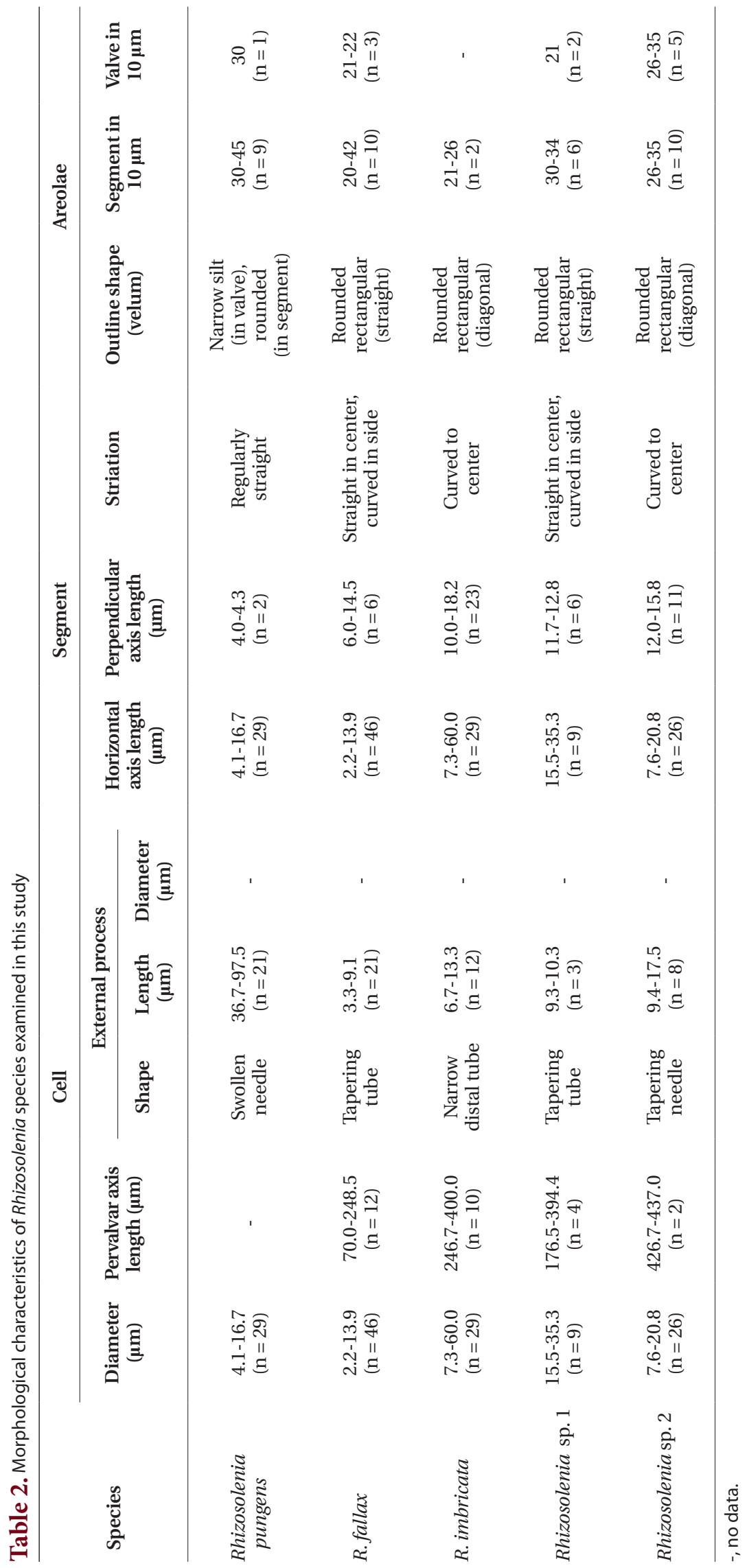



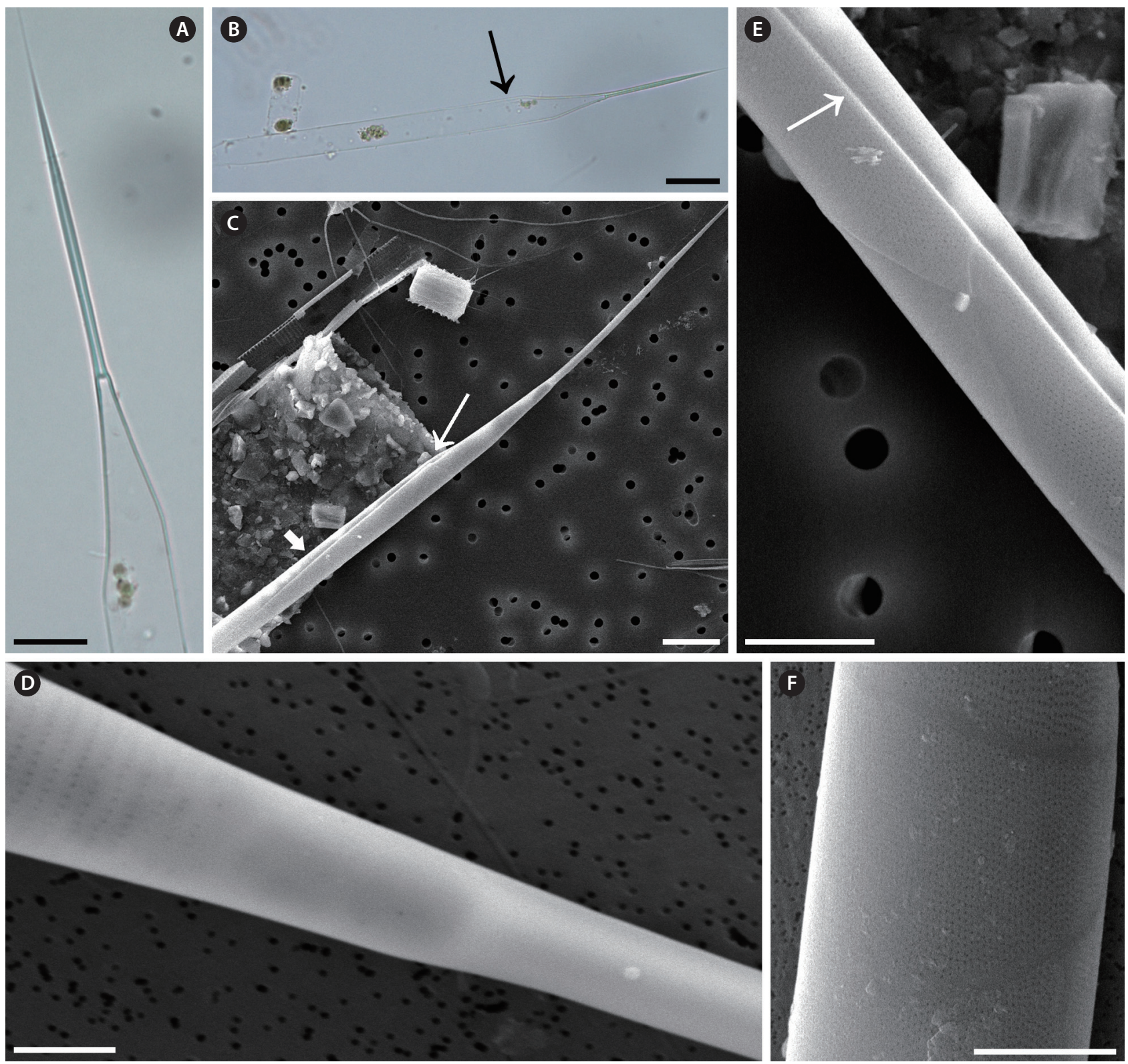

Fig. 1. Rhizosolenia pungens. (A) Apical part of valve, light microscopy (LM). (B) Apical part of valve with invisible clasper (arrow), LM. (C) Apical part of valve, external process, clasper (thin arrow), and thin groove shaped contiguous area (thick arrow), scanning electron microscopy (SEM). (D) Basal part of external process, which lacks otaria, SEM. (E) Thin, groove-shaped contiguous area (arrow), SEM. (F) Detail of areola, one of the narrow, slit-shaped areolae in girdle segments, SEM. Scale bars represent: A \& C, $10 \mu \mathrm{m} ; \mathrm{B}, 20 \mu \mathrm{m} ; \mathrm{D}, 2 \mu \mathrm{m} ; \mathrm{E} \& \mathrm{~F}, 5 \mu \mathrm{m}$.

$\mu \mathrm{m}$ in diameter. The valve is sharply sub-conical, elongated, with a tapering needle-shaped process, almost straight, basally shallow up to the middle and 36.7-97.5 $\mu \mathrm{m}$ in length. A contiguous area is present and otaria are absent. An impression of the adjacent valve process appears from the ventral valvar edge or the advalvar edge. It is groove-shaped and deeper in the basal than in the terminal region. Claspers are poorly noticeable. Valve areolae are poroid, external areolae with slit-like pores, 30 in $10 \mu \mathrm{m}$, and have a secondary quincuncial pattern. Scattered pores are circular, occurring in irregular distribution among the areolae or taking the place of some areolae distinguishable in external view. The segment horizontal and perpendicular axes are 4.1-16.7 $\mu \mathrm{m}$ and 4.0-4.3 $\mu \mathrm{m}$, respectively. Girdle segments are rhomboidal to trapezoidal and arranged in two dorsiventral columns. 
Segment areolae are rounded, 30 to $45 \mathrm{in} 10 \mu \mathrm{m}$, arranged in striae oriented along the pervalvar axis, with a secondary quincuncial pattern.

Distribution. According to Hasle and Syvertsen (1996), R. pungens occurs in brackish waters, both temperate and subtropical (Hernández-Becerril 1995). This species has been found from the coastal waters of the San Jose Gulf (Ferrario et al. 1986) to the San Matias Gulf (Sar 1996). During the present study, we observed it rarely in all samples during February and September 2009, off Jeju Island, Daecheon, Wolseung, Geoje Island, and the Sacheon coast.

Remarks. R. pungens resembles R. setigera in the morphology of its cell shape, claspers, and the thin, grooveshaped contiguous area. However, R. setigera and R. pungens can be distinguished based on the process shape. $R$. pungens appears basally shallow up to the middle of the process, while $R$. setigera possesses a tapering, needleshaped process.

\section{Rhizosolenia fallax Sundström, 1986 (Fig. 2, A-H)}

Sundström 1986, p. 89, Figs 38 \& 227-233; Hasle and Syvertsen 1996, p. 156, Pl. 29.

The cells are solitary, short chains forming, long and narrow cylindrical, bilaterally symmetrical, circular to slightly elliptical in cross-section. Specimens found in Korean coastal waters are 2.2-13.9 $\mu \mathrm{m}$ in diameter and $70.0-248.5 \mu \mathrm{m}$ long. The valve is conoidal to sub-conoidal, bilaterally symmetrical, with the ventral part being much longer than the dorsal part. The contiguous area is large and limited by a well-developed, marginal ridge part, with noticeable claspers. The external process is displaced toward the apex of the apical valve, 3.3-9.1 $\mu \mathrm{m}$ long, wide at the base, becoming tapering and tubular toward the distal part. Otaria are small and extend along the wide, basal part of the process, with the outer margin forming a finely pointed tip. The valve areolae are rounded rectangles, 21-22 in $10 \mu \mathrm{m}$, appearing in striae that converge at the apex. The segment horizontal and perpendicular axes are 2.2-13.9 $\mu \mathrm{m}$ and $6.0-14.5 \mu \mathrm{m}$, respectively. The segments comprise a valvocopula, contiguous with most of the valve margin, and two lateral columns of squamiform to trapezoidal segments with hyaline edges. First segment close to the valvocopula gives the impression of an adjacent valve process at one side. The areolae of segments are rectangular, 20-42 in $10 \mu \mathrm{m}$. Striation in the girdle segments arranged in two patterns; straight in the central region and curved in the marginal region. A middle row of slit pores (usually 3 pores), with their long axes usually parallel to the areolae, perforate the velum structure of the valve and segments.

Distribution. According to Sundström (1986), the distribution of $R$. fallax appeared circumglobal, in temperate to tropical waters. In Korean coastal waters, R. fallax is a newly recorded species. We found it, offshore in oceanic waters, in June 2009 and October 2009 only, in the Yellow Sea and off Geoje Island, Jeju Island, and the Wolseung and Yangyang coasts.

Remarks. Hasle (1975) newly recorded $R$. fallax (as $R$. shrubsolei). She mentioned it as a species in good standing. However, $R$. fallax is difficult to separate from R. imbricata, since it has a similar size range under LM. However, these species can be distinguished by their striations. Moreover, under SEM the two species differ clearly in their velum structures. Likewise, R. fallax and $R$. decipiens are sometimes hard to distinguish by LM. However, the two species can usually be distinguished by process shape, which is basally swollen, then narrows abruptly at the apex, in $R$. fallax but narrows gradually at the apex in $R$. decipiens.

\section{Rhizosolenia imbricata Brightwell, 1858 (Fig. 3, A-H)}

Brightwell 1858, p. 94, Pl. 5, Fig. 6; Van Heurck 18801881, Pl. 79, Figs 5 \& 6; Peragallo 1892, p. 113, Pl. 18, Figs 2 \& 3; Schröder 1906, Fig. 8; Hustedt 1930, p. 580, Fig. 331; Hendey 1964, p. 149, Pl. 3, Fig. 1 as R. imbricata, Fig. 2 as R. shrubsolei; Hasle 1975, p. 107, Pl. 3, Figs 34-36; Navarro 1981, p. 430, Figs 41 \& 42 as R. imbricata var. shrubsolei; Sundström 1986, p. 80, Figs 200-208; Hernández-Becerril 1995, p. 258, Figs 46-49; Hasle and Syvertsen 1996, p. 155, Pl. 29; Sunesen and Sar 2007, p. 634, Figs 48-61.

Synonyms. $R$. shrubsolei Cleve 1881, R. imbricata var. shrubsolei (Cleve) Schröder 1906

The cells are solitary, short chain forming, long cylindrical, bilaterally symmetrical, circular to slightly elliptical in cross-section. Specimens found in Korean coastal waters are 7.3-60.0 $\mu \mathrm{m}$ in diameter, 246.7-400.0 $\mu \mathrm{m}$ long. The valve is obliquely conoidal, with the ventral part being much longer than the dorsal part. The contiguous area is broad, variable in shape, and it is limited by welldeveloped marginal ridges with noticeable claspers. The external process is narrow and distally tube-shaped, displaced toward the apical valve's dorsal apex, 6.7-13.3 $\mu \mathrm{m}$ long. Otaria are comparatively small and extend along the swollen basal part of the process, with the outer margin forming a fine point at the tip. The valve areolae are rounded rectangles arranged in striae, which converge 

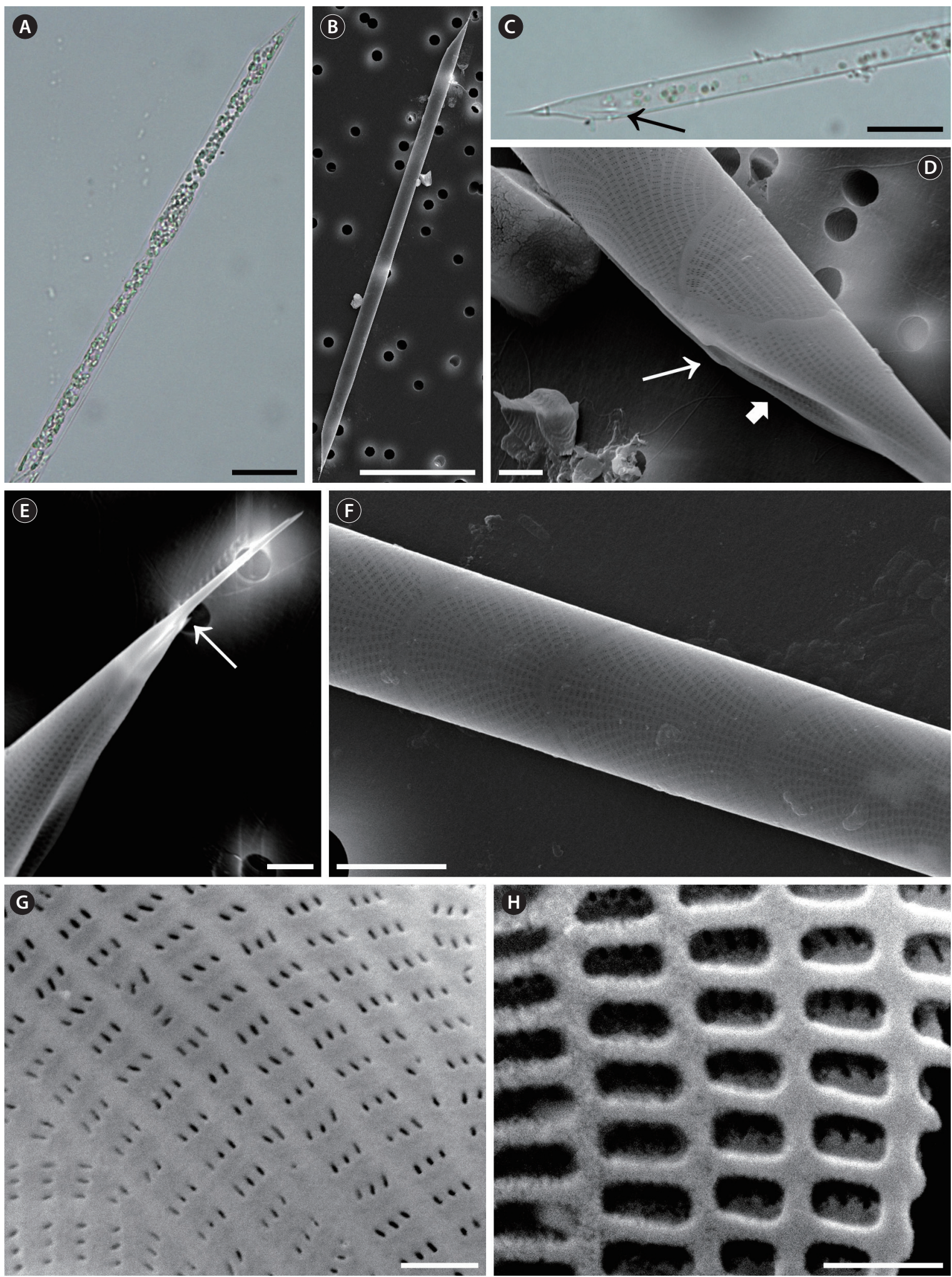

Fig. 2. Rhizosolenia fallax. (A) A complete cell, light microscopy (LM). (B) A complete cell, scanning electron microscopy (SEM). (C) Apical part of valve, showing the noticeable contiguous area (arrow), LM. (D) Clasper (thin arrow) and contiguous area (thick arrow), SEM. (E) Apical part of valve, detail of otaria (arrow), SEM. (F) Girdle segments with striations, straight in central area and curved in marginal area, SEM. (G) Detail of velum structure, external view, SEM. (H) Detail of velum structure, internal view, SEM. Scale bars represent: A, $20 \mu \mathrm{m} ; \mathrm{B}, 50 \mu \mathrm{m} ; \mathrm{C}, 10 \mu \mathrm{m} ; \mathrm{D}$ \& E, $2 \mu \mathrm{m}$; $F, 5 \mu \mathrm{m} ; \mathrm{G} \& \mathrm{H}, 0.5 \mu \mathrm{m}$. 

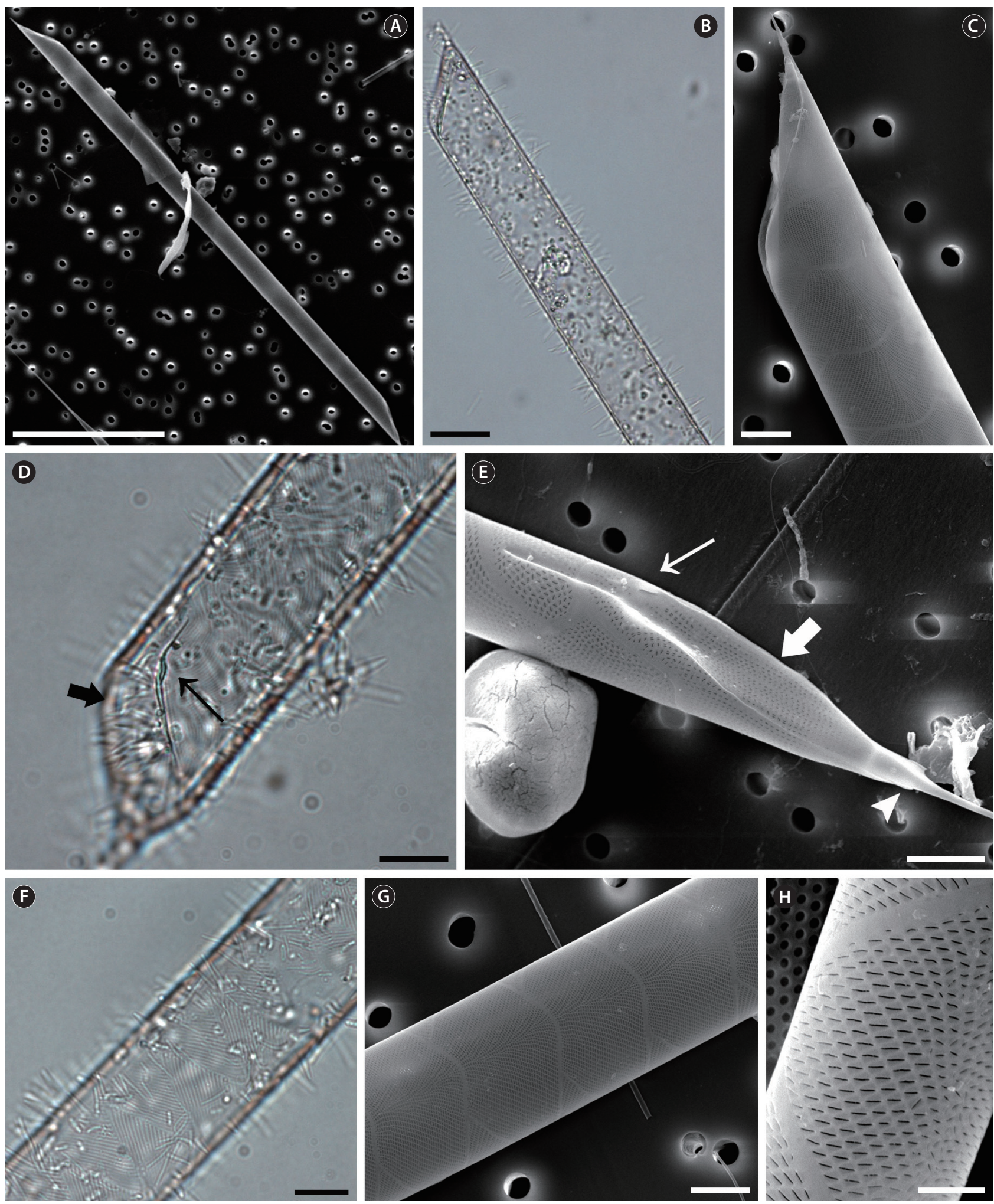

Fig. 3. Rhizosolenia imbricata. (A) A complete cell, scanning electron microscopy (SEM). (B) Apical part of valve, showing the ventral part is much longer than the dorsal part, light microscopy (LM). (C) Apical part of valve, ventral part much longer than dorsal part, SEM. (D) Clasper (thin arrow) and contiguous area (thick arrow), LM. (E) Clasper (thin arrow), contiguous area (thick arrow), and otaria (arrowhead), SEM. (F) Girdle segments, composed of two lateral columns, with striation, showing the curve to central area, LM. (G) Girdle segments with striation, curved to the central area, SEM. (H) Velum structure in girdle segments, SEM. Scale bars represent: A, $100 \mu \mathrm{m} ; \mathrm{B}, 20 \mu \mathrm{m} ; \mathrm{C}, \mathrm{D}, \mathrm{F} \& \mathrm{G}, 10 \mu \mathrm{m} ; \mathrm{E}, 5 \mu \mathrm{m} ; \mathrm{H}, 2 \mu \mathrm{m}$. 
at the apex. The segment horizontal and perpendicular axes are 7.3-60.0 $\mu \mathrm{m}$ and 10.0-18.2 $\mu \mathrm{m}$, respectively. First segment close to the valvocopula bears the impression of the adjacent valve process toward one side. The segments' areolae are rectangular, 21-26 in $10 \mu \mathrm{m}$. Striation in the girdle segments curves toward the central region. A middle row of slit pores (usually 1 pore), with their long axes usually parallel to the areolae, perforate the velum structure of the valve and segments.

Distribution. $R$. imbricata occurs almost everywhere except the polar regions (Sundström 1986, Hasle and Syvertsen 1996), including the Argentinean coastal waters (Vouilloud 2003). During the present study, we sporadically found R. imbricata in Korean coastal waters, in very low abundance.

Remarks. Within its section, Imbricatae's velum structure of the valve areolae and bands is its most important characteristic. In addition, according to Sundström (1986), the velum structure is variable in the species of this section. R. imbricata resembles $R$. striata in general cell shape, striation pattern, and shapes of the valve and segment areolae. Hustedt (1930) and Hendey (1937, 1964), among other authors, considered them to be the same species. However, Sundström (1986) rectified these studies, finding that the two species differ in cross section, which is circular to slightly elliptical in R. imbricata and elliptical in $R$. striata and in process shape. Moreover, they differ in the shape of the otaria, with the outer margin forming a fine point with the distal margin in $R$. imbricata but being rounded in R. striata. Additionally, Sundström (1986) and Hasle and Syvertsen (1996) emphasized that $R$. imbricata has a more pronounced areolae and stria density in the girdle segments (10-18 striae and 23-32 areolae in $10 \mu \mathrm{m})$ than $R$. striata does (6-12 striae and 12-19 areolae in $10 \mu \mathrm{m}$ ).

\section{Rhizosolenia sp. 1 (Fig. 4, A-F)}

Sundström 1986, p. 89, Figs 38 \& 227-233; Hasle and Syvertsen 1996, p. 156, Pl. 29.

The cells are solitary, short chain forming, long and narrow cylindrical, bilaterally symmetrical, circular to slightly elliptical in cross-section. Specimens are 15.5$35.3 \mu \mathrm{m}$ in diameter and 176.5-394.4 $\mu \mathrm{m}$ long. The valve is conoidal to sub-conoidal, bilaterally symmetrical, with the ventral part being much longer than the dorsal part. contiguous area is broad, limited by a well-developed, marginal ridge part, with noticeable claspers. The external process is displaced toward the apical valve's apex, 9.3-10.3 $\mu \mathrm{m}$ long, and wide at the base, with a tapering tube shape toward the distal part. Otaria are small, extended along the wide basal part of the process, with the outer margin forming a fine point at the tip. The valve areolae are rounded rectangles, 21 in $10 \mu \mathrm{m}$, arranged in striae converging at the apex. The segment horizontal and perpendicular axes are 15.5-35.3 $\mu \mathrm{m}$ and 11.7-12.8 $\mu \mathrm{m}$, respectively. The segments comprise a valvocopula, contiguous with most of the valve margin, and squamiform to trapezoidal segments with hyaline edges, in two lateral columns. First segment close to the valvocopula shows the impression of the adjacent valve process toward one side. The areolae of segments are rectangular, 30-34 in $10 \mu \mathrm{m}$. Striation in the girdle segment arranged in two patterns: straight in the central region and curved in the marginal region. The velum structure of valve and segments are perforated by a middle row of slit pores (usually 3 pores) with long axes usually parallel to the areolae.

Distribution. In September 2008, we newly observed Rhizosolenia sp. 1 within Korean coastal waters, in the Yellow Sea's oceanic waters.

Remarks. Rhizosolenia sp. 1 shows the common characteristics of R. fallax. Both Rhizosolenia sp. 1 and R. fallax show the same velum structure and striation patterns. However, the diameter of the Rhizosolenia sp. 1 that we observed in Korean coastal waters was double that of the previously studied $R$. fallax.

\section{Rhizosolenia sp. 2 (Fig. 5, A-E)}

Brightwell 1858, p. 94, Pl. 5, Fig. 6; Van Heurck 18801881, Pl. 79, Figs 5 \& 6; Peragallo 1892, p. 113, Pl. 18, Figs 2 \& 3; Schröder 1906, Fig. 8; Hustedt 1930, p. 580, Fig. 331; Hendey 1964, p. 149, Pl. 3, Fig. 1 as R. imbricata, Fig. 2 as R. shrubsolei; Hasle 1975, p. 107, Pl. 3, Figs 34-36; Navarro 1981, p. 430, Figs $41 \& 42$ as R. imbricata var. shrubsolei; Sundström 1986, p. 80, Figs 200-208; Hernández-Becerril 1995, p. 258, Figs 46-49; Hasle and Syvertsen 1996, p. 155, Pl. 29; Sunesen and Sar 2007, p. 634, Figs 48-61.

The cells are solitary, short chain forming, long cylindrical, bilaterally symmetrical, circular to slightly ellipti$\mathrm{cal}$ in cross-section. Specimens are 7.6-20.8 $\mu \mathrm{m}$ in diameter, $426.7-437.0 \mu \mathrm{m}$ long. The valve is obliquely conoidal, with the ventral part much longer than the dorsal part. The broad contiguous area is limited by well-developed marginal ridges, with noticeable claspers. The external process is narrow, distally tubular, displaced toward the dorsal apex of the apical valve, 9.4-17.5 $\mu \mathrm{m}$ long. Otaria are comparatively small, extending along the swollen basal part of the process, with the outer margin form- 

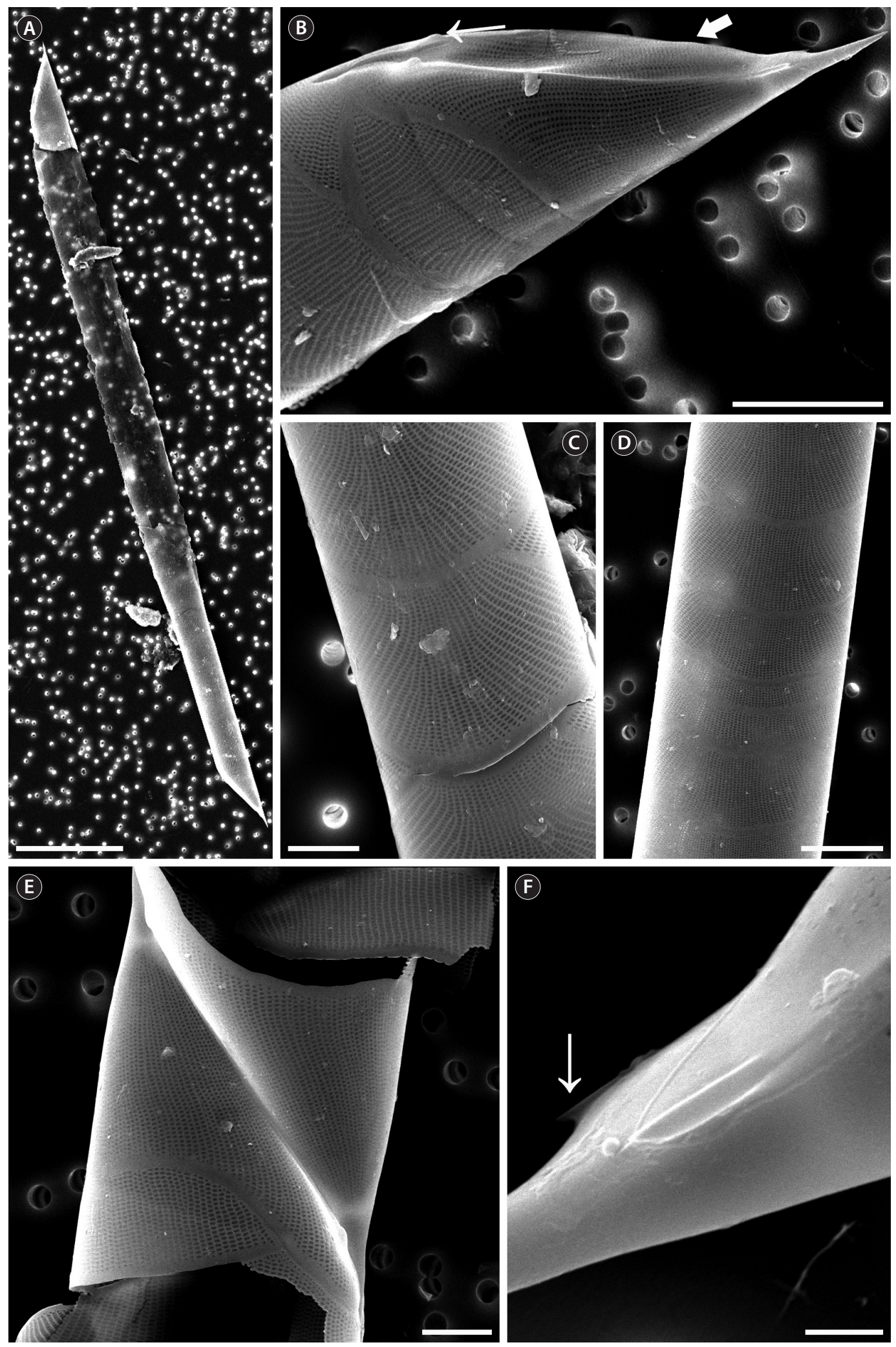

Fig. 4. Rhizosolenia sp. 1. (A) A collapsed cell, with ventral part much longer than dorsal part, scanning electron microscopy (SEM). (B) Clasper (thin arrow) and contiguous area (thick arrow), SEM. (C) Detail of girdle segments with striation, straight in central area and curved in marginal area, SEM. (D) Girdle segments, SEM. (E) Connection between two cells, SEM. (F) Detail of otaria (arrow), SEM. Scale bars represent: A, 50 mm; B \& D, 10 $\mu \mathrm{m} ; \mathrm{C} \& \mathrm{E}, 5 \mu \mathrm{m} ; \mathrm{F}, 1 \mu \mathrm{m}$. 

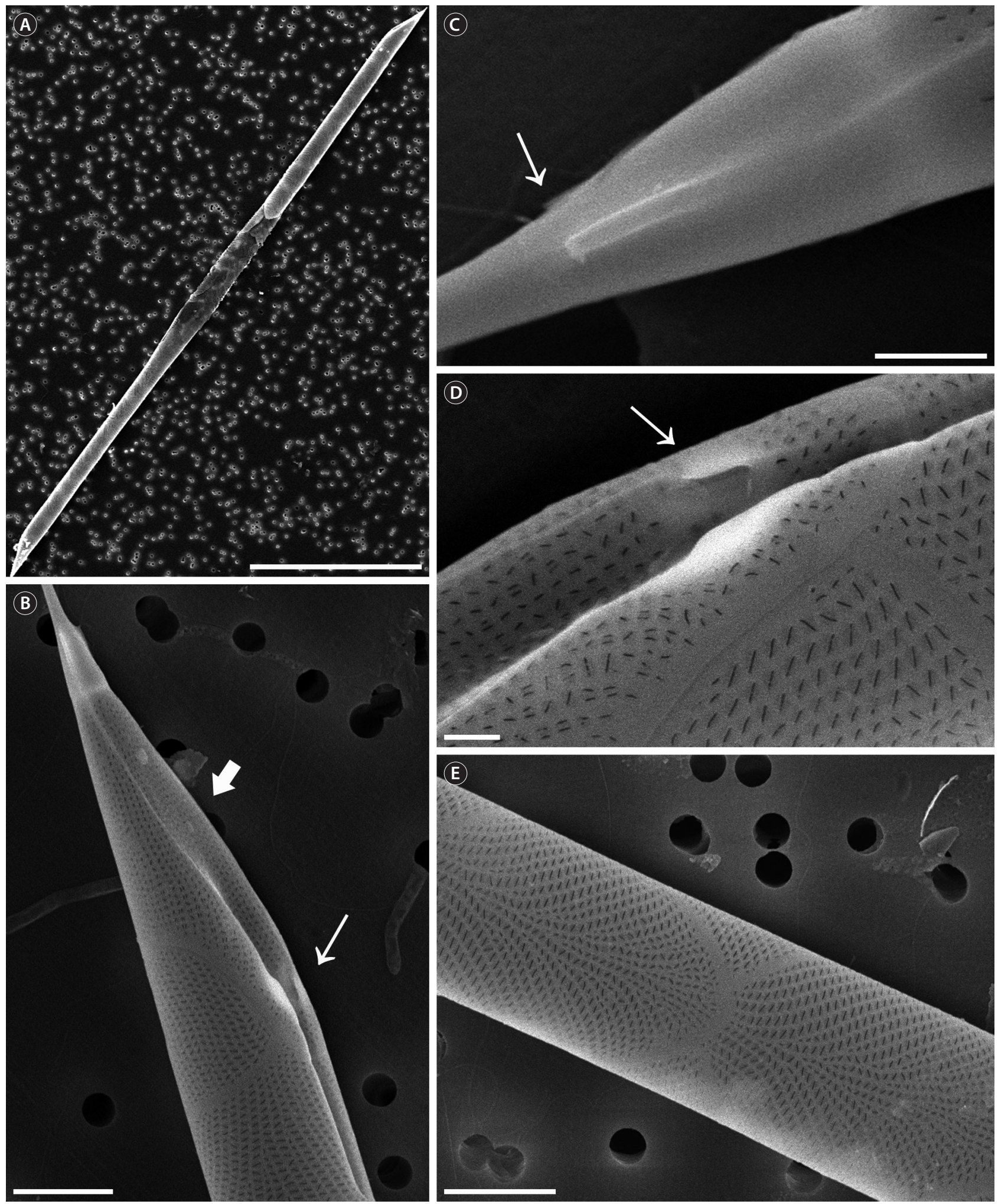

Fig. 5. Rhizosolenia sp. 2. (A) A complete cell, ventral part much longer than dorsal part, scanning electron microscopy (SEM). (B) Apical part of valve, showing clasper (thin arrow) and contiguous area (thick arrow), SEM. (C) Detail of otaria (arrow), SEM. (D) Detail of clasper (arrow), SEM. (E) Detail of girdle segments with striation, curved to central area and velum structure, SEM. Scale bars represent: $A, 100 \mu \mathrm{m} ; B$ \& E, $5 \mu \mathrm{m} ; C$ \& D, $1 \mu \mathrm{m}$. 
ing a fine point at the tip. The valve areolae are rounded rectangles, arranged in striae converging at the apex. The segment horizontal and perpendicular axes are 7.6-20.8 $\mu \mathrm{m}$ and 12.0-15.8 $\mu \mathrm{m}$, respectively. First segment close to the valvocopula shows the impression of the adjacent valve process toward one side. The areolae of segments are rectangular, 26-35 in $10 \mu \mathrm{m}$. Striation in the girdle segments curves toward the central region. The velum structure of valve and segments are perforated by a middle row of slit pores (usually 1 pore) with the long axes commonly parallel to the areolae.

Distribution. In September 2008, we newly observed Rhizosolenia sp. 2 within Korean coastal waters, in the Yellow Sea's oceanic waters.

Remarks. Rhizosolenia sp. 2 resembles $R$. imbricata in the morphology of its striation and velum structure. However, areolae density distinguishes this species from R. imbricata; Rhizosolenia sp. 2 has 21-26 in $10 \mu \mathrm{m}$, while R. imbricata has 26-35 in $10 \mu \mathrm{m}$.

\section{DISCUSSION}

In the present study, we recorded 5 species (including 2 unidentified species) belonging to the genus Rhizosolenia. Two species had already been recorded in Korean coastal waters: R. pungens (Shim 1994, Lee 1995) and $R$. imbricata (Shim 1994, Lee 1995). R. fallax, Rhizosolenia sp. 1 and Rhizosolenia sp. 2 were newly recorded within Korean coastal waters, though occurring rarely in our samples. R. fallax and R. pungens were widely distributed at Jeju Island (St. 6 and St. 5), respectively. We found these species in our samples all along the Korean coast. However, we found R. imbricata sporadically, at 1 station in the Yellow Sea.

According to Brunel (1962), R. pungens is a variation of $R$. setigera Brightwell, based on its conoidal valves and the shape and arrangement of its girdle segments and areolae. However, the two species differ in process morphology. Sunesen and Sar (2007) described some specimens with tapering, external processes of common appearance and others with a thick middle part, along with specimens having intermediately-thickened processes, all occurring in the same sample. Nevertheless, Hasle and Syvertsen (1996) and Throndsen et al. (2003) dealt with two distinct species, based on external process morphology.

Sundström (1986) hesitated to consider R. setigera as belonging to the genus Rhizosolenia at all, because the species did not clearly fit into either of the two sections (section Rhizosolenia and Imbricatae) of the genus Rhizosolenia. Both R. setigera and R. pungens differ in having thin, groove-shaped contiguous areas and in their areolae morphologies, they lack otaria, and their poroids show a velum structure with slit-shaped pores. From a morphological point of view, the important characteristics of the species R. setigera and R. pungens are their thin, grooveshaped contiguous areas with claspers. If the contiguous area locate on the first ventral segment and lacks otaria, as in the case of $R$. bergonii, those species should belong to the section Rhizosolenia. As a result, the characteristics of $R$. setigera and R. pungens are insufficient to establish a new genus. Thus, $R$. setigera and $R$. pungens are included in the genus Rhizosolenia, based on ultrastructural similarities of this species to other species of the genus.

$R$. fallax, newly observed in Korean coastal waters, is characterized by its velum structure and striations. Sundström (1986) illustrated its velum structure and striation, and these features are important characteristics of the section Imbricatae of the Rhizosoleniaceae. Further details remain to be investigated, and other section Imbricatae species that occur in Korean waters should be studies soon.

We provide here a key to the representatives of the genus Rhizosolenia that we discovered during the present survey. Rhizosolenia species commonly exhibit a girdle segment structure in the column, a particular shape to their external processes, otaria, claspers, and a contiguous area (Sundström 1986, Hasle and Syvertsen 1996).

\section{ACKNOWLEDGEMENTS}

This research was supported by the Project on Survey and Excavation of Korean Indigenous Species of the National Institute of Biological Resources (NIBR), under the Ministry of the Environment, and by a Mid-career Research Program of the National Research Foundation of Korea (NRF) grant (funded by MEST, No. 2010-0027713) to J. H. Lee. We would like to thank Prof. Hans-U. Dahms in the Department of Green Life Science, Sangmyung University for critical reading and comments on an earlier manuscript draft and for language improvements. Thanks also to all who helped with sample collection and technical assistance in this study, Dr. S. W. Jung and Mrs. H. M. Joo, J. S. Park, and J. M. Lee in the Department of Green Life Science, Sangmyung University, Korea. 


\section{REFERENCES}

Brightwell, T. 1858. Remarks on the genus 'Rhizosolenia' of Ehrenberg. Q. J. Microsc. Sci. 6:93-95.

Brunel, J. 1962. Le phytoplancton de la Baie des Chaleurs. Contributions du Ministère de la Chasse et des Pecheries 91:1-365.

Cleve, P. T. 1881. On some new and little known diatoms. Kungl. Svenska Vet. Akad. Handl. 18:1-28.

Cupp, E. E. 1943. Marine plankton diatoms of the west coast of North America. Bull. Scripps Inst. Oceanogr. 5:1-238.

Edlund, M. B. \& Stoermer, E. F. 1993. Resting spores of the freshwater diatoms Acanthoceras and Urosolenia. J. Paleolimnol. 9:55-61.

Ehrenberg, C. G. 1843. Verbreitung und Einfluss des mikroskopischen Lebens in Süd- und Nord-Amerika. Abh. Königl. Akad. Wiss. Berlin 1:291-445.

Ferrario, M. E., Sar, E. A. \& Codina, R. G. 1986. Diatomeas marinas de la Provincia de Chubut (República Argentina). Centrales I. Darwiniana 27:89-106.

Hasle, G. R. 1975. Some living marine species of the diatom family Rhizosoleniaceae. Nova Hedwigia Beih. 53:99153.

Hasle, G. R. \& Fryxell, G. A. 1970. Diatoms: cleaning and mounting for light and electron microscopy. Trans. Am. Microsc. Soc. 89:469-474.

Hasle, G. R. \& Syvertsen, E. E. 1996. Marine diatoms. In Tomas, C. R. (Ed.) Identifying Marine Diatoms and Dinoflagellates. Academic Press, San Diego, CA, pp. 5-385.

Hendey, N. I. 1937. The plankton diatoms of the Southern Seas. Discov. Rep. 16:151-364.

Hendey, N. I. 1964. An introductory account of the smaller algae of British coastal waters. Part 5: Bacillariophyceae (Diatoms). Her Majesty's Stationery Office, London, 317 pp.

Hernández-Becerril, D. U. 1995. Planktonic diatoms from the Gulf of California and coasts off Baja California: the genera Rhizosolenia, Proboscia, Pseudosolenia, and former Rhizosolenia species. Diatom Res. 10:251-267.

Hernández-Becerril, D. U. \& Meave del Castillo, M. E. 1996. The marine planktonic diatom Rhizosolenia robusta (Bacillariophyta): morphological studies support its transfer to a new genus, Calyptrella gen. nov. Phycologia 35:198-203.

Hernández-Becerril, D. U. \& Meave del Castillo, M. E. 1997. Neocalyptrella, gen, nov., a new name to replace Calyptrella Hernández-Becerril et Meave. Phycologia 36:329.

Hustedt, F. 1930. Die Kieselalgen Deutschlands, Österreichs und der Schweiz mit Berückichtigung der übrigen Län- der Europas sowie der angrenzende Meeresgebiete. In Rabenhorst, L. (Ed.) Kryptogamen-Flora von Deutschland, Österreich und der Schweiz. Akademische Verlagsgesellschaft m. b. H., Leipzig. pp. 1-920.

Lee, J. H. 1995. Additional check-list of marine planktonic algae in the coastal waters of Korea. I. Bacillariophyceae. J. Nat. Sci. Sangmyung Women's Univ. 2:71-198.

Navarro, J. N. 1981. A survey of the marine diatoms of Puerto Rico. I. Suborders Coscinodiscineae and Rhizosoleniineae. Bot. Mar. 24:427-439.

Peragallo, H. 1892. Monographie du genre Rhizosolenia et de quelques genres voisins. Diatomiste 1:1-39.

Ross, R., Cox, E. J., Karayeva, N. I., Mann, D. G., Paddock, T. B. B., Simonsen, R. \& Sims, P. A. 1979. An amended terminology for the siliceous components of the diatom cell. Nova Hedwigia Beih. 64:513-533.

Rott, E., Kling, H. \& McGregor, G. 2006. Studies on the diatom Urosolenia Round \& Crawford (Rhizosoleniophycideae) part I. New and reclassified species from subtropical and tropical freshwaters. Diatom Res. 21:105-124.

Round, F. E., Crawford, R. M. \& Mann, D. G. 1990. The diatoms: biology and morphology of the genera. Cambridge University Press, London, 747 pp.

Sar, E. A. 1996. Flora diatomológica de Bahía San Antonio (Prov. de Río Negro, Argentina) O. Centrales I. Rev. Mus. La Plata (Nueva Ser.) 14:365-400.

Schröder, B. 1906. Beiträge zur Kenntnis des Phytoplanktons warmer Meere. Vierteljahrsschr. Naturforsch. Ges. Zuer. 51:319-377.

Shim, J. H. 1994. Illustrated encyclopedia of fauna \& flora of Korea, vol. 34 Marine phytoplankton. Ministry of Education, Seoul, pp.1-487.

Simonsen, R. 1974. The diatom plankton of the Indian Ocean Expedition of R/V “Meteor” 1964-1965. Meteor Forsch. Ergeb. Reihe D. 19:1-107.

Sundström, B. G. 1986. The marine diatom genus Rhizosolenia: a new approach to the taxonomy. Ph.D. dissertation, Lund University, Lund, Sweden, 117 pp.

Sunesen, I. \& Sar, E. A. 2007. Marine diatoms from Buenos Aires coastal waters (Argentina). IV. Rhizosolenia s. str., Neocalyptrella, Pseudosolenia, Proboscia. Phycologia 46:628-643.

Throndsen, J., Hasle, G. R. \& Tangen, K. 2003. Norsk Kystplankton Flora. Almater Forlag AS, Oslo, 341 pp.

Van Heurck, H. F. 1880-1881. Synopsis des diatomées de Belgique. Atlas, Anvers.

Vouilloud, A. A. 2003. Catálogo de diatomeas continentales y marinas de Argentina. Versión 1.0. Asociación Argentina de Ficologia, La Plata, 304 pp. 